\title{
The effects of 5-hydroxytryptophan on carrageenan-induced mouse paw oedemas
}

\author{
Efeito de 5-hidroxitriptofano no edema \\ de pata de camundongo induzido \\ por carragenina
}

\author{
Gokçen TELLI' ID 0000-0003-0028-6769 \\ Inci KAZKAYASI ${ }^{1}$ iD) 0000-0003-1159-9680 \\ Serdar UMA1 ID) 0000-0003-4064-6319
}

A B S T R A C T

\section{Objective}

5-Hydroxytryptophan is the precursor compound of serotonin biosynthesis. The oral absorption of 5-Hydroxytryptophan is close to $100 \%$ and, unlike serotonin, it crosses the blood-brain barrier freely. 5-Hydroxytryptophan has been used as a food supplement for many years to treat anxiety and depression. Recent studies have shown that 5-Hydroxytryptophan suppresses the pro-inflammatory mediators and is effective in some inflammatory diseases, such as arthritis and allergic asthma. However, the role of 5 -Hydroxytryptophan supplements on acute peripheral inflammation has not been investigated yet. In this study, the in vivo anti-inflammatory activity of 5-Hydroxytryptophan was evaluated with a carrageenan-induced paw oedema test in mice.

\section{Methods}

For the investigation of the acute antiinflammatory activity, single oral doses of 5-Hydroxytryptophan (1.5, 5 and $20 \mathrm{mg} / \mathrm{kg}$ ) were given to mice 1.5 hours prior to the carrageenan test. For chronic activity, the same oral doses were administered daily for two weeks prior to the carrageenan test on the $14^{\text {th }}$ day. To induce inflammation, $0.01 \mathrm{~mL}$ of $2 \%$ carrageenan was injected into the paws of mice.

\section{Results}

Supplementation with 5-Hydroxytryptophan significantly reduced inflammation in a dose-independent manner which was irrespective of the duration of exposure (per cent inhibition in acute experiments was $35.4 \%, 20.9 \%, 24.0 \%$,

\footnotetext{
${ }^{1}$ Hacettepe University, Faculty of Pharmacy, Department of Pharmacology. Sihhiye Campus, 06100, Ankara, Turkey. Correspondence to: G TELLI. E-mail: <gokcentelli@hacettepe.edu.tr>.

How to cite this article

Telli G, Kazkayasi I, Uma S. The effects of 5-Hydroxytryptophan on carrageenan-induced mouse paw oedemas. Rev Nutr. 2021;34:e200119. https://doi.org/10.1590/1678-9865202134e200119
} 
and per cent inhibition in chronic experiments was 29.5\%, 35.3\%, 40.8\% for the doses of 1.5, 5, and 20mg/kg, respectively).

\section{Conclusion}

Our findings demonstrate for the first time that 5-HTP supplements have the potential of suppressing the measures of acute peripheral inflammation. It is suggested that, apart from several diseases where serotonin is believed to play an important role, including depression, patients with inflammatory conditions may also benefit from 5-HTP.

Keywords: 5-hydroxytryptophan. Anti-Inflammatory agents. Carrageenan. Dietary supplements.

\section{R E S U M O}

\section{Objetivo}

O 5-hidroxitriptofano (5-HTP) é o composto precursor da biossíntese da serotonina. A absorção oral do 5-HTP é próxima a $100 \%$ e, ao contrário da serotonina, atravessa a barreira hematoencefálica livremente. O 5-HTP tem sido usado como suplemento alimentar por muitos anos na ansiedade e na depressão. Estudos recentes demonstraram que o 5-HTP suprime os mediadores pró-inflamatórios e é eficaz em algumas doenças inflamatórias, como artrite e asma alérgica. No entanto, o papel dos suplementos de 5-HTP na inflamação periférica aguda ainda não foi investigado. Neste estudo, a atividade anti-inflamatória in vivo do 5-HTP foi avaliada por meio do teste de edema de pata induzido por carragenina em ratos.

\section{Métodos}

Para a atividade aguda, doses orais únicas de 5 -HTP (1,5, 5 e 20 mg/kg) foram dados aos ratos 1,5 horas antes do teste da carragenina. Para a atividade crônica, as mesmas doses orais foram dadas cada dia durante duas semanas antes do teste da carragenina no $14^{\circ}$ dia. 0,01 $\mathrm{ml}$ da carragenina a $2 \%$ foi injetado nas patas dos ratos a fim de induzir a inflamação.

\section{Resultados}

A suplementação com 5-HTP reduziu significativamente a inflamação de uma maneira independente da dose, que foi independente da duração da exposição (por cento de inibição em experimentos agudos; 35,4\%, 20,9\%, 24,0\% e por cento de inibição em experimentos crônicos; 29,5\%, 35,3\%, 40,8\% para as doses de 1.5, 5 e 20 mg/kg respectivamente).

\section{Conclusão}

Nossas conclusões demonstram pela primeira vez que os suplementos de 5-HTP têm potencial para suprimir os sintomas de inflamação periférica aguda. É sugerido que, além de várias doenças em que se acredita que a serotonina tem uma função importante, incluindo a depressão, os pacientes com doenças inflamatórias também podem se beneficiar do 5-HTP.

Palavras-chave: 5-hidroxitriptofano. Anti-Inflamatórios. Carragenina. Suplementos dietéticos.

\section{NTRODUCTION}

5-hydroxytriptophan (5-HTP) is the intermediate metabolite of the serotonin biosynthesis. The production of 5-HTP from the amino acid L-tryptophan by tryptophan hydroxylase is the rate-limiting step in the synthesis of serotonin. Certain factors like stress and insulin resistance affect this step, leading to the decrease of serotonin production [1-3]. Brain serotonin level is mostly dependent on 5-HTP which, in contrast to serotonin, easily crosses the blood-brain barrier and is almost fully absorbed from an oral dose $[4,5]$. Therefore, 5-HTP has become a frequently used supplement for the treatment of anxiety and depression for many years and its efficacy in these illnesses has been shown by several clinical trials [6, 7].

It is also suggested that 5-HTP is an important antioxidant [8-10]. In this regard, it inhibits oxidative damage and apoptosis through the downregulation of reactive species and inducible nitric oxide synthase expression in human fibroblast cells [11]. In recent years, studies searching the anti-inflammatory activity 
of 5-HTP have started to increase. Accordingly, the production of Interleukin (IL)-17 has been reported to have decreased with 5-HTP treatment in human peripheral blood mononuclear cells [12]. In RAW 264.7 cells (Murine Macrophage Cell Line), 5-HTP reduced lipopolysaccharide-induced production of NO and IL-6 via preventing cyclooxygenase-2 and inducible nitric oxide synthase expression [13].

However, there are few studies conducted on animals with respect to its anti-inflammatory activity. In mice, 5-HTP treatment was found to reduce LPS-induced serum TNF-alpha levels [14]. In another study, it is reported that allergic lung inflammations induced by different asthma models were inhibited with 5-HTP supplementation in mice [15]. Also in arthritis, which is another chronic inflammatory condition, the progress of the disease is supressed in mice given the 5-HTP supplement one week before the induction of inflammation [16]. Different cells and chemical mediators play roles in the responses of the body against acute and chronic inflammation. Generally, neutrophils are the predominant cells of the acute inflammation, whereas macrophages and lymphocytes are the primary cells of chronic inflammation and several chemical mediators such as kinins, prostaglandins, leukotrienes, and cytokines (IL-1, IL-6) are released from these immune cells [17].

Although there are in vitro studies investigating the 5-HTP effect on acute inflammation, to our knowledge, information in the literature about 5-HTP action on acute inflammation in intact animals is lacking. Therefore, in this study we aimed to see if the administration of such inflammations with 5-HTP would reduce the acute peripheral inflammation induced by subplantar carrageenan injection in mice. The experiments were designed so as to compare the activity of three different doses of 5-HTP with indomethacin, used as reference drug $[12,13]$.

\section{METHODS}

Male Swiss albino mice (8-12 weeks old, weighing 20-25g) were used in the experiments. The animals were housed in a room at constant temperature $\left(22^{\circ} \mathrm{C}\right)$ under a $12 \mathrm{~h}$ day $/ 12 \mathrm{~h}$ night period and had ad libitum access to food and water. All animal experiments were performed with the approval of the Kobay DHL A.Ş. Local Ethics Board (2019/472).

The supplement of 5-HTP (Nature's Bounty) was administered to mice at doses of 1.5, 5, and 20mg/ $\mathrm{kg} /$ day dissolved into $0.5 \mathrm{~mL}$ water with oral gavage. Each group of mice received only one dose of 5-HTP $(n=8)$. The acute anti-inflammatory effect was measured after a single administration of each dose of 5-HTP and the chronic effect was evaluated following daily supplementation of the same doses for 14 days. Doses of 1.5 and $5 \mathrm{mg} / \mathrm{kg}$ were selected in order to mimic those used in humans and $20 \mathrm{mg} / \mathrm{kg}$ was selected as the highest dose $[15,16]$. For control, water, as vehicle, was applied orally at the same volume given to 5-HTP groups. In another group of mice, oral indomethacin (Sigma-Aldrich, Germany) $(10 \mathrm{mg} / \mathrm{kg}$ ) was used as a positive control $(n=8)$.

In vivo anti-inflammatory activity was assessed with modified carrageenan-induced mice paw oedema tests [18]. Inflammation was induced by a sub-plantar injection of $0.01 \mathrm{~mL} 2 \%$ carrageenan (Sigma-Aldrich, Germany) into the right hind paw of mice. Inflammation-induced oedema was calculated by measuring the changes in paw thickness with a dial thickness gauge (0.01-1Mm, Ozaki Co., Japan) just before $\left(n_{0}\right)$ and 2 hours after $(n)$ the carrageenan injection; $\left(\Delta\right.$ oedema $\left.=n-n_{0}\right)$. To assess the acute anti-inflammatory activity of 5-HTP, the carrageenan test was done 1.5 hours after oral gavage. For the evaluation of chronic efficacy, animals were subjected to carrageenan 1.5 hours after the last 5-HTP supplementation given at the end of the $14^{\text {th }}$ day. The decrease in $\Delta$ oedema indicates to the anti-inflammatory activity. Per cent inhibition of inflammation was calculated according to the formula below: 
Anti-inflammatory activity $(\%)=[($ Control $\Delta n-5-H T P \Delta n)] /$ Control $\Delta n] \times 100$

The statistical analysis was performed using one-way ANOVA and post hoc Dunnett's test or Student's $t$ test (GraphPad Prism version 5.0.0 Software Windows, GraphPad Software, San Diego, California USA). Data were expressed as mean \pm standard error of mean and a $p$ value of less than 0.05 was considered to be statistically significant.

\section{RE S U LT S}

Acute supplementation with 5-HTP produced a significant reduction in carrageenan-induced paw oedema at all doses, compared to control $(p<0.05, n=8$ in each group, anti-inflammatory activities (\% of control) are 35.4, 20.9, 24.0 for the doses of 1.5, 5, and 20mg/kg, respectively). However, the amount of suppression did not show statistical significance among the doses (Figure 1). Similarly, indomethacin caused a marked reduction in paw oedema compared to control $(p<0.05, n=8$ in each group, anti-inflammatory activities (\% of control) are 29.5, 35.3, 40.8 for the doses of 1.5, 5 and $20 \mathrm{mg} / \mathrm{kg}$, respectively) that was not significantly different from those evoked by 5 -HTP doses (Figure 1).

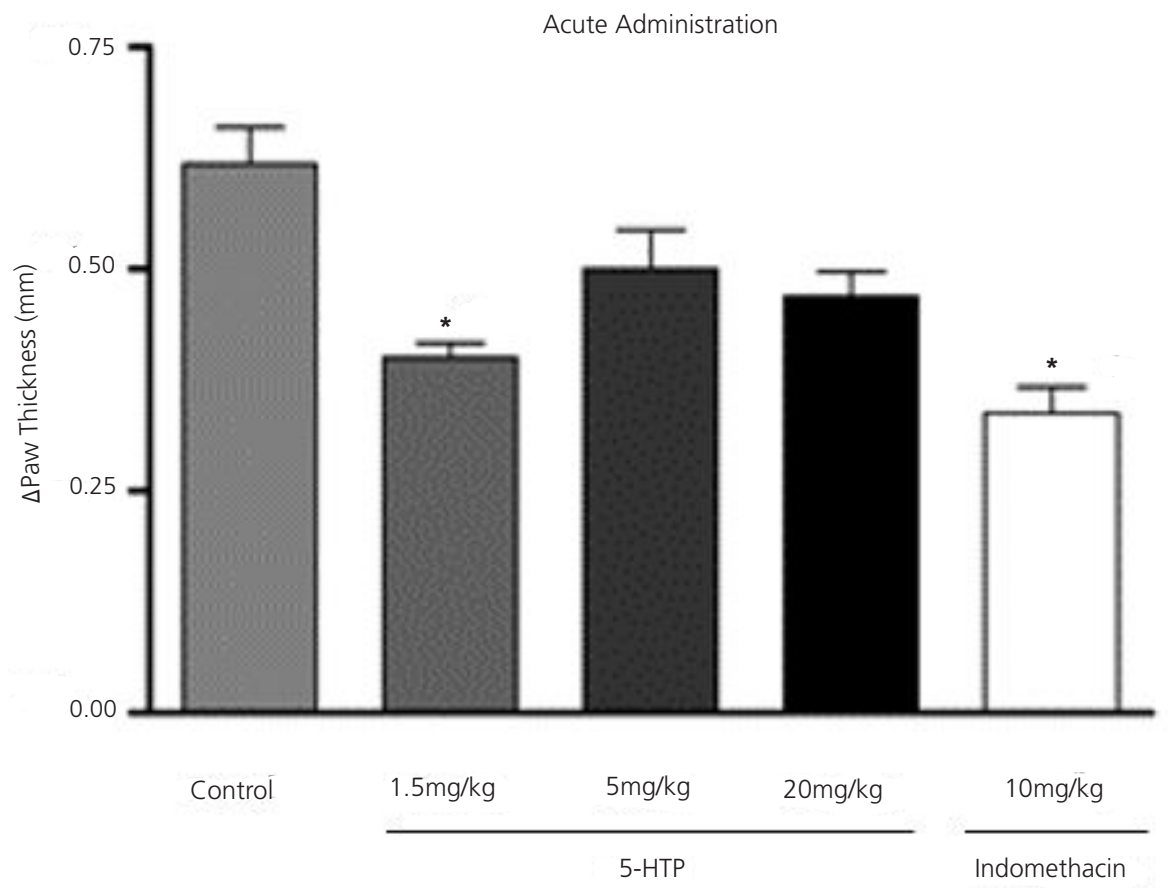

Figure $1-\triangle$ Paw thickness of the mice with acute administration of 5-HTP. Statistical analysis was performed using a one-way ANOVA post hoc Dunnet's test. Data are expressed as mean \pm SEM ( $n=8$ for each group).

Note: ${ }^{*} p<0.05$ compared with control group.

Chronic supplementation with 5-HTP also provided an apparent reduction in carrageenaninduced paw oedema at all doses, compared to control group. Although the inhibition tended to rise with increasing doses, it failed to reach to statistical significance (Figure 2, $p<0.05, \mathrm{n}=8$ for each group). The extent of inhibition caused by either acute or chronic administrations of 5-HTP did not differ significantly at any dose. 


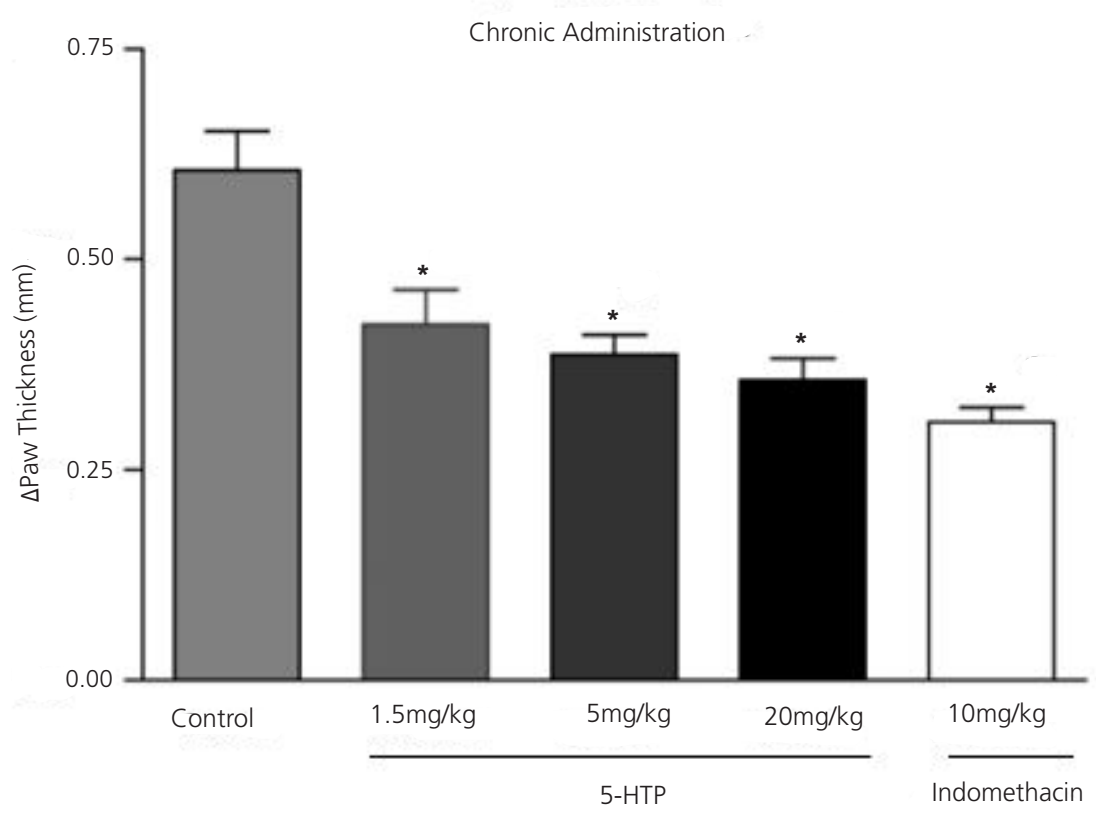

Figure $2-\triangle$ Paw thickness of the mice after chronic administration of 5-HTP. Statistical analysis was performed using a one-way ANOVA post hoc Dunnet's test. Data are expressed as mean \pm SEM ( $n=8$ for each group).

Note: ${ }^{*} p<0.05$ compared with control group.

\section{DISCUSSION}

The use of 5-HTP supplements against certain central nervous system-related diseases has increased substantially over the last decades $[5,6,19]$. Moreover, important anti-oxidant and anti-inflammatory effects of 5-HTP obtained with in vitro studies have also been reported $[8,9,11,14,19]$. Selective serotonin reuptake inhibitors known to elevate brain serotonin levels, besides their anti-depressant activity, are claimed to have potent anti-inflammatory activity with unknown mechanisms [20-22]. Therefore, it can be expected that 5-HTP, as the precursor of serotonin in brain, may display anti-inflammatory effects as well.

Hence, it has been reported that 5-HTP administration reduces the pulmonary inflammation in different animal models of allergic asthma [15]. In support of this, it is demonstrated that the prophylactic administration of 5-HTP suppressed the inflammation in the arthritic joints of mice [16]. However, despite these published reports, there is no in vivo evidence in the literature concerning the influence of oral supplementation with 5-HTP on acutely-induced peripheral inflammation.

Carrageenan induced mouse/rat paw edema test is one of the basic models used for investigating new anti-inflammatory drugs as well as for studying the mechanisms involved in inflammation. The present study demonstrated for the first time that oral supplementation of the mice with 5-HTP, either acutely or chronically, reduced the inflammation induced by sub-plantar carrageenan injection in a dose-independent manner. This all-or-none mode of action was an unexpected finding. Our results do not provide evidence on whether 5-HTP exerts its inhibitory effect on the inflammatory process by its own or via conversion to serotonin. If it is due to serotonin production, the dose-independent mode of action could be the result of its biphasic effect on inflammation as suggested before $[21,23,24]$. An alternative explanation for the failure of higher doses of 5-HTP to enhance anti-inflammatory effects could be due to the decreased production of serotonin in response to high doses of 5-HTP due to less availability of the enzyme aromatic amino acid 
decarboxylase [15]. Nevertheless, a possible direct action of 5-HTP, per se, on the inflammatory process cannot be excluded. Supporting that affirmation, Chae et al. [13] showed that, in the presence of NSD-1015 which supresses the transformation of 5-HTP into serotonin, 5-HTP still reduced the inflammatory mediators in the mice macrophage cell line.

Taken together, the mechanisms underlying the relation between serotonin and inflammation is likely to be complicated and remains unknown. The comparable degree of reduction in paw oedema of the mice treated either with acute or chronic 5-HTP supplement, leads us to suggest that the duration of exposure is not crucial for the development of anti-inflammatory effect. However, since the mechanism underlying this effect was not in the scope of this work, additional experiments are required to clarify this issue.

\section{CONCLUSION}

At present, nonsteroidal anti-inflammatory agents are the drugs of choice for the treatment of acute inflammation. However, these medications have significant side effects such as gastrointestinal disorders [25]. Therefore, new therapies with less unwanted effects will be important in inflammation-related diseases. This study introduces the first in vivo evidence that supplementation with 5-HTP alleviates the symptoms of acute peripheral inflammation. It should be noted that depressive disorders are also common in patients suffering from inflammatory diseases. Therefore, when the indistinguishable activity between 5-HTP and indomethacin is taken into consideration, 5-HTP could be a promising therapeutic approach and may even be the therapy of choice in such patients.

\section{CONTRIBUTORS}

G TELLI worked on the study's conception and design, performed the experiments and data analysis, and wrote the manuscript draft. I KAZKAYASI worked on the study's conception and design, performed the experiments and data analysis. S UMA worked on the study's conception and design, data interpretation, review, editing, and finalisation of the manuscript.

\section{REFERENCES}

1. Oh CM, Park S, Kim H. Serotonin as a new therapeutic target for diabetes mellitus and obesity. Diabetes Metab J. 2016;40(2):89-98. https://doi.org/10.4093/dmj.2016.40.2.89

2. Kim K, Oh CM, Ohara-Imaizumi M, Park S, Namkung J, Yadav VK, et al. Functional role of serotonin in insulin secretion in a diet-induced insulin-resistant state. Endocrinology. 2015;156(2):444-52. https://doi.org/10.1210/ en.2014-1687

3. Natarajan R, Northrop NA, Yamamoto BK. Protracted effects of chronic stress on serotonin-dependent thermoregulation. Stress. 2015;18(6):668-76. https://doi.org/10.3109/10253890.2015.1087502

4. Sharma A, Castellani RJ, Smith MA, Muresanu DF, Dey PK, Sharma HS. 5-Hydroxytryptophan: a precursor of serotonin influences regional blood-brain barrier breakdown, cerebral blood flow, brain edema formation, and neuropathology. Int Rev Neurobiol. 2019;146:1-44. https://doi.org/10.1016/bs.irn.2019.06.005

5. Xu D, Fang M, Wang $H$, Huang $L, X u Q, X u Z$. Enhanced production of 5-hydroxytryptophan through the regulation of L-tryptophan biosynthetic pathway. Appl Microbiol Biotechnol. 2020;104(6):2481-8. https://doi.org/10.1007/ s00253-020-10371-y

6. Jacobsen JPR, Krystal AD, Krishnan KRR, Caron MG. Adjunctive 5-Hydroxytryptophan slow-release for treatment-resistant depression: clinical and preclinical rationale. Trends Pharmacol Sci. 2016;37(11):933-44. https://doi.org/10.1016/j. tips.2016.09.001

7. Weinberg-WolfH, Fagan NA, Anderson GM, Tringides M, Dal Monte O, Chang SWC. The effects of 5-hydroxytryptophan on attention and central serotonin neurochemistry in the rhesus macaque. Neuropsychopharmacology. 2018;43(7):1589-98. https://doi.org/10.1038/s41386-017-0003-7 
8. Sudhamani H, Syam Prasad G, Venkataramaiah C, Raju CN, Rajendra W. In silico and in vitro antioxidant activity profiles of urea and thiourea derivatives of 5-hydroxytryptophan. J Recept Signal Transduct Res. 2019;39(4):373-81. https://doi.org/10.1080/10799893.2019.1683864

9. Kayacan Y, Yazar H, Kisa EC, Ghojebeigloo BE. A novel biomarker explaining the role of oxidative stress in exercise and I-tyrosine supplementation: thiol/disulphide homeostasis. Arch Physiol Biochem. 2018;124(3):232-6. https://doi. org/10.1080/13813455.2017.1388410

10. Martinez Medina JJ, Naso LG, Perez AL, Rizzi A, Okulik NB, Valcarcel M, et al. Synthesis, characterization, theoretical studies and biological (antioxidant, anticancer, toxicity and neuroprotective) determinations of a copper(II) complex with 5-hydroxytryptophan. Biomed Pharmacother. 2019;111:414-26. https://doi.org/10.1016/j.biopha.2018.12.098

11. Bae SJ, Lee JS, Kim JM, Lee EK, Han YK, Kim HJ, et al. 5-Hydroxytrytophan inhibits tert-butylhydroperoxide (t-BHP)induced oxidative damage via the suppression of reactive species (RS) and nuclear factor-kappaB (NF-kappaB) activation on human fibroblast. J Agric Food Chem. 2010;58(10):6387-94. https://doi.org/10.1021/jf904201h

12. Cheng SC, Van de Veerdonk F, Smeekens S, Joosten LA, Van der Meer JW, Kullberg BJ, et al. Candida albicans dampens host defense by downregulating IL-17 production. J Immunol. 2010;185(4):2450-7. https://doi. org/10.4049/jimmunol.1000756

13. Chae HS, Kang OH, Choi JG, Oh YC, Lee YS, Jang HJ, et al. 5-hydroxytryptophan acts on the mitogen-activated protein kinase extracellular-signal regulated protein kinase pathway to modulate cyclooxygenase-2 and inducible nitric oxide synthase expression in RAW 264.7 cells. Biol Pharm Bull. 2009;32(4):553-7. https://doi.org/10.1248/ bpb.32.553

14. Ohgi Y, Futamura T, Kikuchi T, Hashimoto K. Effects of antidepressants on alternations in serum cytokines and depressive-like behavior in mice after lipopolysaccharide administration. Pharmacol Biochem Behav. 2013;103(4):853-9. https://doi.org/10.1016/j.pbb.2012.12.003

15. Abdala-Valencia H, Berdnikovs S, McCary CA, Urick D, Mahadevia R, Marchese ME, et al. Inhibition of allergic inflammation by supplementation with 5-hydroxytryptophan. Am J Physiol Lung Cell Mol Physiol. 2012;303(8):L642-60. https://doi.org/10.1152/ajplung.00406.2011

16. Yang TH, Hsu PY, Meng M, Su CC. Supplement of 5-hydroxytryptophan before induction suppresses inflammation and collagen-induced arthritis. Arthritis Res Ther. 2015;17:364. https://doi.org/10.1186/s13075-015-0884-y

17. Kantari C, Pederzoli-Ribeil M, Witko-Sarsat V. The role of neutrophils and monocytes in innate immunity. Contrib Microbiol. 2008;15:118-46. https://doi.org/10.1159/000136335

18. Sarigol D, Uzgoren-Baran A, Tel BC, Somuncuoglu El, Kazkayasi I, Ozadali-Sari K, et al. Novel thiazolo[3,2-b]-1,2,4triazoles derived from naproxen with analgesic/anti-inflammatory properties: synthesis, biological evaluation and molecular modeling studies. Bioorg Med Chem. 2015;23(10):2518-28. https://doi.org/10.1016/j.bmc.2015.03.049

19. Galano A, Castaneda-Arriaga R, Perez-Gonzalez A, Tan DX, Reiter RJ. Phenolic melatonin-related compounds: their role as chemical protectors against oxidative stress. Molecules. 2016;21(11). https://doi.org/10.3390/ molecules21111442

20. Galecki P, Mossakowska-Wojcik J, Talarowska M. The anti-inflammatory mechanism of antidepressants: SSRIs, SNRIs. Prog Neuropsychopharmacol Biol Psychiatry. 2018;80(PtC):291-4. https://doi.org/10.1016/j.pnpbp.2017.03.016

21. Wu H, Denna TH, Storkersen JN, Gerriets VA. Beyond a neurotransmitter: the role of serotonin in inflammation and immunity. Pharmacol Res. 2019;140:100-14. https://doi.org/10.1016/j.phrs.2018.06.015

22. Eskeland S, Halvorsen JA, Tanum L. Antidepressants have anti-inflammatory effects that may be relevant to dermatology: a systematic review. Acta Derm Venereol. 2017;97(8):897-905. https://doi.org/10.2340/00015555-2702

23. Schuff-Werner $P$, Splettstoesser W. Antioxidative properties of serotonin and the bactericidal function of polymorphonuclear phagocytes. Adv Exp Med Biol. 1999;467:321-5. https://doi.org/10.1007/978-1-4615-4709-9_41

24. Shajib MS, Khan WI. The role of serotonin and its receptors in activation of immune responses and inflammation. Acta Physiol (Oxf). 2015;213(3):561-74. https://doi.org/10.1111/apha.12430

25. Harirforoosh S, Asghar W, Jamali F. Adverse effects of nonsteroidal antiinflammatory drugs: an update of gastrointestinal, cardiovascular and renal complications. J Pharm Pharm Sci. 2013;16(5):821-47. https://doi. org/10.18433/j3vw2f 